\title{
CHARACTERIZATION OF THE WORKFORCE IN COMMERCIAL RESTAURANTS: an analysis of the bars and restaurants around the Reta da Base Aérea de Santa Cruz, Rio De Janeiro/RJ
}

\author{
Rafaela Terra da Fonseca ${ }^{a}$ \\ Dan Gabriel D'Onofreb
}

\begin{abstract}
Located in the West Zone of the city of Rio de Janeiro city, Santa Cruz is the fourth most populous neighborhood in Brazil and has an important history from the colonial and imperial periods. However, there are a number of aspects that have not yet been addressed by academics, such as the way restaurant businesses are organized in the neighborhood. This paper aims to provide a socioeconomic profile characterization of those who work in the bars, restaurants, and similar businesses around the Reta da Base Aérea de Santa Cruz. To this end, it uses exploratory techniques, such as bibliographic research and fieldwork with participant observation and filling out of forms, to gather information to comprise a socioeconomic profile of the workforce, including work relationships, characterization of the businesses, and the types of foods offered. Finally, the importance of this research is highlighted for use in tourism planning of the region.
\end{abstract}

\section{Keywords:}

Restaurants

Workforce

Tertiary Sector

Hospitality 


\section{INTRODUCTION}

In Brazil, there has been a significant increase in the number of people dining out. According to a regional analysis conducted by the Brazilian Institute of Geography and Statistics [IBGE] (2019a), the highest expenditure on food outside the home is in the Center-West (38.0\%) and Southeast (34.2\%) regions of Brazil, which are above the national average of $32.8 \%$ spent by the Brazilian population on food. According to the Brazilian Association of Bars and Restaurants (Abrasel), the out-of-home food sector represents $2.7 \%$ of the current national GDP, comprising a million businesses and generating around six million jobs and making it the sector that employs the highest number of people in Brazil (Abrasel, 2020). A survey conducted by GS\& Gouvêa de Souza Group ${ }^{1}$ for the Foodservice Brazil Institute (IFB) shows that in 2018 alone, the sector had a turnover of $\mathrm{R} \$ 205$ billion, and that it is comprised mainly of independent restaurants, with a wide variety of concepts and smaller businesses (Diário do comércio, 2019).

Despite its importance to the Brazilian economy, many aspects of the service sector have not yet been studied by academics. One example is the way commerce and services are organized in the food sector, which includes establishments such as bars, restaurants, snack bars and pizzarias. Little is known, for example, about the profile of those who work in this sector, particularly outside the main tourist areas or in more remote or less affluent neighborhoods. For this study, we selected an area where commercial food services cater mainly for the local population of Santa Cruz. This neighborhood, located in the West Zone (Zone Oeste) of the city of Rio de Janeiro, was selected not only because of the feasibility of conducting research there, but also because of its socioeconomic context. Santa Cruz is the fourth most populous neighborhood in Brazil and has an important and rich history from the colonial and imperial periods. But despite this, the neighborhood still lacks integrated development strategies that can help it reach its potential for welcoming visitors to the area.

As a possible basis for a tourism plan at the area, this paper investigates the socioeconomic profile characterization of those who work in the commercial food services around the Reta da Base Aérea de Santa Cruz, the road that leads to the Santa Cruz Air Force Base, and now an important leisure space for the local population, with the presence of many bars and restaurants. For this study, exploratory techniques were used, including bibliographic research and fieldwork, with participant observation and filling out of forms, to gather information on the socioeconomic profile of those working at bars, restaurants and other, similar businesses in this Santa Cruz territorial sample, as well as the work relationships, and the types of businesses and the food services offered.

\section{METHODOLOGY}

Given the lack of similar studies to ours, we used exploratory strategies to conduct the process. As regards the field of study, given that it focuses on businesses located on the outskirts of the city, with a significant percentage of informal businesses, it was considered that a purely quantitative study, with the application of forms without the due care, might cause the interviewees to feel constrained. Therefore, although the approach used is quantitative, the procedures used were also guided by qualitative research techniques.

First, a bibliographic review was carried out, with a historical research, to define the conceptual field of the restaurants in the Santa Cruz neighborhood. After this stage, fieldwork was conducted from February to March 2020. This included mapping the commercial food businesses around the Reta da Base Aérea de Santa Cruz, with participant observation and visits to local restaurants, interviews with key informers, and the use of two types of forms, one for the restaurant managers/owners and the other for the employees, as described in Table 1.

Table 1: Application of Forms

\begin{tabular}{l|l}
\hline \multicolumn{1}{c|}{ FORM 1 } & \multicolumn{1}{c}{ FORM 2 } \\
\hline $\begin{array}{l}\text { Filled out by the manag- } \\
\text { ers and/or owners }\end{array}$ & Filled out by the employees \\
\hline $\begin{array}{l}\text { Aimed to gather infor- } \\
\text { mation about the charac- } \\
\text { terization of the business- } \\
\text { es }\end{array}$ & $\begin{array}{l}\text { Aimed to gather information } \\
\text { about the employees' socioec- } \\
\text { onomic profile, and also about } \\
\text { the dynamics of their work } \\
\text { relationships }\end{array}$ \\
\hline $\begin{array}{l}16 \text { types of restaurants } \\
\text { open for business were } \\
\text { identified }\end{array}$ & $\begin{array}{l}17 \text { available employees were } \\
\text { found during the days of the } \\
\text { fieldwork }\end{array}$ \\
\hline 15 forms fill out & 13 forms filled out \\
\hline
\end{tabular}

Source: Elaborated by the authors.

The forms were prepared based on questions developed from October 2019 to January 2020, and were applied by the authors themselves. Before applying the forms in the field, a pre-test was carried out to check their effectiveness. A table with closed questions was decided on, as it was thought this would facilitate the 
statistical data analysis process.

During the research, some difficulties were encountered, mainly in relation to the application of the forms. Some of the interviewees showed mistrust and refused to fill out the forms due to the presence of questions of a socioeconomic nature, which they considered "too personal", even though they were presented with a letter explaining the nature of the research. But in general, most of the respondents were happy to fill out the forms.

The data were analyzed using the research method of triangulation, articulating the results from the fieldwork with secondary research developed by other authors, including the National Household Sample Survey (PNAD).

\section{OUTLINING THE FIELD OF STUDY: THE CONCEPT OF COMMERCIAL RESTAURANTS}

This paper aims to provide an overview of the workforce of restaurants in Santa Cruz. Gomes (2008) believes that idea of workforce can be characterized as

(...) the capacity of the group of individuals who participate in the economic process, holders of physical and mental abilities that already exist in the human body or are acquired through experience and basic education, accumulated form one generation to the next, and that the human being sets in motion when producing values of use (Gomes, 2008, p. 19) [Free translation].

Commercial restaurants are understood, by Camargo (2003), as a theoretical field of study in hospitality. Therefore, this section will be developed based on an investigation of the concept of hospitality, which will be seen from a commercial perspective, focusing specifically on commercial catering establishments.

Hospitality can be defined as any activity of which society forms the basis. It includes the acts of welcoming, hosting, feeding and entertaining, carried out in the domestic, private, public, commercial or virtual environments and involving the concepts of mutuality and exchange (Camargo, 2003; Lashley, 2004). According to Lashley (2004), hospitality can be divided into three areas: social, private and commercial. Each area portrays an aspect offered by hospitality, functioning independently and overlapping with one another. The same author also states that:

the social domain of hospitality considers the social scenarios in which hospitality, and the acts connected to hospitality, occur along with the impacts of social forces on the production and consumption of food, beverages and accommodation. The private domain focuses on issues associated with the offer of this "tiad" in the home, and also considers the impact of the relationship between guest and host. The commercial area is about the offer of hospitality as an economic activity, and includes the activities of both private and public sectors (Lashley, 2004, p. 5) [Free translation].

According to Camargo (2003), hospitality can be thought as two axes of time/space: the cultural axis, which considers actions involving the concept of hospitality, and are the actions of welcoming, hosting, feeding and entertaining; and the social axis, which corresponds to the types of social interaction and their resulting physical-environmental areas, including the domestic, public, commercial and virtual spheres. In other words, the cultural axis is dedicated to temporal aspects, while the social axis relates to spatial aspects.

Following Camargo's (2003) line of thought, it is conceived that hospitality comprises social aspects such as the acts of welcoming or receiving. According to same author, these actions mean giving shelter to those who knock on the door, emphasizing that hospitality, rather than being considered a gesture related to the social life, is a ritual of the private life. To host refers to the act of offering accommodation and shelter to guests, bearing in mind, also, that the idea of hospitality does not necessarily involve the act of hosting. The act of feeding considers that in some cultures, offering food demarcates and makes true the act of hospitality. The act of entertaining, meanwhile, considers that hosting people means entertaining them in some form (Camargo, 2003).

The domestic context, as a category of the social axis of the hospitality, considers that the act of receiving visitors in the home, seen from a historical perspective, is the most characteristic form of hospitality and also the most complex one, seen from the perspective of rites and meanings. The public context corresponds to hospitality that takes place due to the right to come and go, and consequently, "to have ones expectations for human interaction met, and to be understood, both in the everyday urban life that favors the residents and in the tourist dimension and the wider political dimension" (Camargo, 2003, p. 16) [Free translation].

The commercial context comprises the modern commercial structures created due to the emergence of modern tourism and which are commonly referred to as hotel business and restaurants. Finally, the virtual context, although associated and found in the other three previous categories, is understood by some specific characteristics of this hospitality, such as its ubiquity. The sender and the receiver of the message are seen as host and guest, respectively, with all the consequences that this relationship implies 
(Camargo, 2003).

The cultural and social axes, when connected, create sixteen fields of study within hospitality. One of these is commercial food, or restaurants, which is focused on food businesses (Camargo, 2003). As stated by Camargo (2003), a gastronomic standard emerges in a particular place when the quality of the food offered in professional environments, such as restaurants, is better than the food prepared at home.

The same author also indicates the elements related to the work environment, such as replacing the terms cook with chef, reinforcing the idea of the existence of a commercial food field. From the sociological point of view, the study of the act of leaving home, as an economic ritual and an act of social visibility, must include "the concern for the restaurant's job market and the transformation of old serving jobs into more glamorous, better paid ones, under the names of maîtres, hostess, chefs etc." (Camargo, 2003, p. 24) [Free translation].

Taking into account these aspects, it is evident that a study of the workforce of the restaurants around the Reta da Base Aérea de Santa Cruz can contribute to an understanding of a consolidated commercial food area in the neighborhood. Based on this, it is necessary to understand how the current economy has emerged in the Santa Cruz neighborhood, and consequently, how the gastronomic center was formed in this location. These topics will be addressed in the next section.

\section{FROM COLONIAL ESTATE TO} THE RETA DA BASE AÉREA DE SANTA CRUZ: FROM AN

\section{AGRARIAN ECONOMY TO ECONOMIC DIVERSITY}

The economy of the neighborhood of Santa Cruz began with the Portuguese invasion (Machado, 2013a). From 1589 onwards, the Jesuit priests took control of the area, exploiting the indigenous and Afro-Brazilian slaves for agriculture and cattle farming (Machado, 2013a; Mansur, 2008). In 1759, the Jesuits were expelled from the country by the order of the Marquis of Pombal, and their lands and properties were seized by the Portuguese government. The Fazenda Santa Cruz was placed under the administration of the Viceroys (Mansur, 2008).

The estate then went through a period of abandonment and corruption, until the arrival of the royal family in Brazil in 1808, when the Prince Regent D. João VI was charmed by the west region, and chose the fields of Santa Cruz as the site of his summer holidays. Thus, a series of changes were made to the old Jesuit monastery, turning it into the Santa Cruz Royal Palace. The road connecting the area to the center of the city, previously called the Jesuit Path, was also improved, becoming the Estrada Real de Santa Cruz (Santa Cruz Royal Path). All these changes led to frequent visits to the estate by dignitaries, nobles, important artists and European naturalists (Mansur, 2008), bringing with them a series of aristocratic elements to the lifestyle of the elite who inhabited the region, once marked by ecclesiastical aspects. The presence of these visitors may have led to new demands for positions related to hospitality, which is a subject that could be further investigated in subsequent studies.

During the reign of Dom Pedro II, the neighborhood went through a process to industrialize its agribusiness, starting with the inauguration of a slaughterhouse in 1881, in the presence of the emperor D. Pedro II. The Matadouro de Santa Cruz (Santa Cruz Slaughterhouse) supplied meat to the entire population of Rio de Janeiro and was, in its day, the most modern in the world. Thanks to its electricity generator, the Santa Cruz slaughterhouse was the first remote neighborhood to have electric lights. With the arrival of agro-industrialization, jobs sprang up that had hitherto not existed. Two new workers' villages were built to house the workers and their families (Machado, 2013c; Mansur, 2008).

Santa Cruz underwent another cycle of economic expansion in 1930, during the Getúlio Vargas government, receiving several sanitation works and the creation of agrarian colonies (Mansur, 2008). Over the years, the fields gave way to factories (Machado, 2013b). The Santa Cruz Industrial Zone emerged in the 1960 s, resulting in many major companies such as the Cosigua Gerdau and Valesul steel plants, boosting the local economy to become, today, one of the most important economic areas in the west of the city (Machado, 2013b; Mansur, 2008; Oliveira, 2017).

With these historical transformations that took place in the process of development of Santa Cruz, the economy changed from being largely based on agriculture and cattle farming to one based on industry, commerce and services, including commercial food businesses. Nowadays, Santa Cruz is an area of economic diversity that includes agricultural production; the industrial center, which is home to major plants, such as Ternium Brasil, one of the major steel manufacturers in Latin America, and the Brazilian National Mint. The commerce and services sector has also shown significant growth in recent years.

\section{Santa Cruz Air Base (BASC)}

In 1930, during the cycle of economic expansion of Santa Cruz under the Getúlio Vargas government, international commercial aviation consisted of German 
airships known as Zeppelins, with the Graf Zeppelin making the first experimental trip from Germany to Brazil. In 1933, "the Germans from the company Luftschiffbau Zeppelin were in Rio de Janeiro, the Brazilian capital at that time, to choose the most suitable spot to serve as the landing field and definitive hanger for their enormous airships" (Agência Força Aérea, 2016 , p. 1) [Free translation]. A piece of land located in the Santa Cruz neighborhood, and belonging to the Ministry of Agriculture, was chosen. In 1934 the construction of the Bartolomeu Gusmão Airport, to house the airships, began. That construction was the origin of the present-day Santa Cruz Air Base, a major military unit of the Brazilian Air Force (FAB) (Agência Força Aérea, 2016).

Hence, in 1936, Santa Cruz was home to the only airship hangar in the world, built to house the famous Hindengurg and the Zeppelin (Mansur, 2008; Oliveira, 2017), "with the opertion of a regular flight connecting Germany to Brazil" (Agência Força Aérea, 2016, p. 1) [Free translation]. The hangar was also the base for the first Jet Fighter Aviation Group from the Brazilian Air Force, which was active during the Second World War. Since 1998, the hangar has been considered a heritage site by the National Historic and Artistic Heritage Institute (IPHAN), under registration number 550. Today, it houses the aircraft of the Santa Cruz Air Base (Mansur, 2008).

Although fully operational, the Santa Cruz Air Base opens its doors to public visitors. A small memorial center was built at the site containing an explanatory guide, showing visitors the history of airships and of the Air Base and its surrounding neighborhood (Souza, 2003).

Other initiatives geared towards the culture of this important space in Santa Cruz were developed, such as the initiative of Oscar Niemeyer, who designed a monument to honor the Brazilian aviators who took part in the Second World War (Costa, 2013). This monument is part of the external tourist circuit, along with the hangar and the enormous metal sphere where the hydrogen was stored that supplies the airships, now transformed into a huge terrestrial globe where the international routes covered by the Graff Zeppelin and the Hindenburg can be seen, even from far off. Today, the commanders, officers and privates who serve at the Santa Cruz Air Base are conscious of the historical importance of the aerotactic complex, and hold events or form partnerships with governmental bodies, institutions and teaching organizations, as well as nongovernmental organizations, to promote visits by tourists and the local community to the various memorial spaces at the BASC (Souza, 2003, p. 8). [Free translation]

By offering visits to visit the Santa Cruz Air Base as a leisure option, an opportunity was opened up for the emergence of a service network to support the activity, i.e., to cater for the visitors' demands. In addition to the fact that the Santa Cruz Air Base is, in itself, an element that requires good access infrastructure, being located in one of the best places for transportation in Santa Cruz, there was also a demand for a service infrastructure to cater not only for the Air Base itself, but also for all the workers who live and work in Santa Cruz.

Hence, on Rua do Império, popularly known as the Reta da Base Aérea de Santa Cruz, one of the main access routes to the Santa Cruz Air Base, a gastronomic area emerged to cater for workers and also local inhabitants of the neighborhood.

A gastronomic center can be defined as an urban area where several activities of different types - in this case gastronomical - are gathered, so that people can circulate among the different establishments (Soares, 2016). For a better understanding of a gastronomic center, it is necessary to mention the definition of tourist center. According to Petrocchi (2002 as cited in Fratucci, 2002), the tourist phenomenon is characterized by the formation of an series of elements, including accommodation, food and leisure, which structure themselves around natural or historical-cultural areas. Also according to Petrocchi (2002 as cited in Fratucci, 2002, p. 1), the concept of a center is synonymous with "cluster", which is proposed by Porter as a "cluster of industries and institutions that maintain strong connections between them, both horizontally and vertically" [Free translation] and it functions as a methodological resource for the development and planning of tourist activities.

Therefore, for a location to be characterized as a gastronomic center, it must have certain elements in place, such as: gastronomic establishments (bars, restaurants, snack bars, etc.), and the presence of people who will make up the workforce and the clientele of these establishments (Brandão \& Pereira, 2010) [Free translation]. The presence of these elements enables the study of these restaurants that compose the gastronomic center of the Reta da Base Aérea de Santa Cruz and its workforce, which we shall address in the sections that follow.

\section{THE PROFILE OF THE COM- MERCIAL RESTAURANTS AROUND THE RETA DA BASE AÉREA DE SANTA CRUZ: FO- CUS ON THE WORKFORCE}

In a preliminary fieldwork mapping conducted from February to March 2020, the following restaurants were identified on the Reta da Base Aérea de Santa Cruz (Picture 1): 
Figure 1 - Commercial restaurants on the Reta da Base Aérea de Santa Cruz
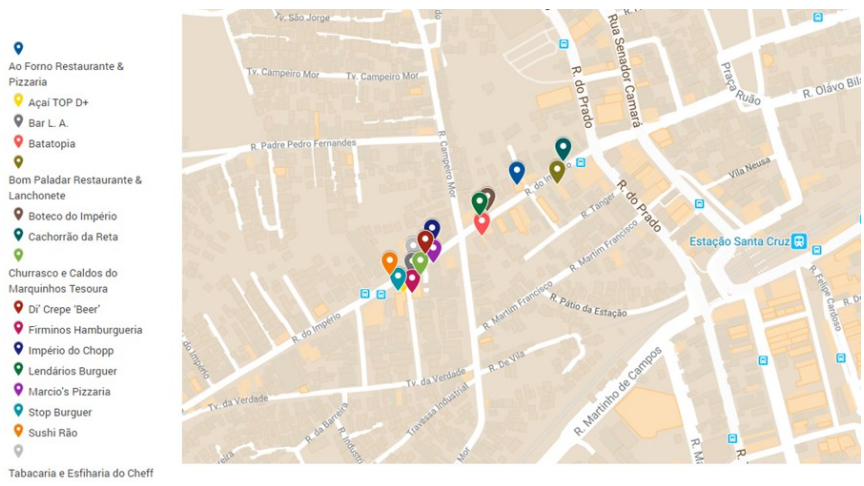

Source: Elaborated by the authors.

\section{Profile of restaurants around the Reta da Base Aé- rea de Santa Cruz}

Form 1 was applied to the managers/owners of the commercial food businesses around the Reta da Base Aérea de Santa Cruz, seeking to gather information that would characterize these businesses. Sixteen restaurants were identified that were open for business. Of these, 15 forms were filled out, by the managers/ owners of six different types of restaurant: a la carte restaurants $(33.3 \%)$, snack bars $(33.3 \%)$, street food stands $^{2}(13.3 \%)$, bar (6.7\%), self-service restaurant (6.7\%), and bar/snack bar ${ }^{3}(6.7 \%)$.

Most of the business surveyed, corresponding to $80 \%$, were managed by family or relatives. The majority had up to 5 employees (93.3\%). Corroborating the result of the fieldwork, Lucas (1995 as cited in Guerrier \& Adib, 2004 , p. 363) states that the hospitality sector includes a high number of small business, often family-owned and run, with an average of 4 or 5 each. The employee positions at the establishments surveyed were: waiter/ waitress $(66.7 \%)$, cook (66.7\%), receptionist $(66.7 \%)$, cashier $(46.7 \%)$, manager $(26.7 \%)$, chef $(13.3 \%)$, sushiman (13.3\%), pizza chef (13.3\%), barbecue griller (6.7\%), barman (6.7\%), deliverer (6.7\%) and fry cook (6.7\%).

It was also observed that the restaurants around the Reta da Base Aérea de Santa Cruz provide a wide variety of dishes and food. Also corroborating these results, Salay (2005) describes the large presence of small businesses and the diversity of dishes offered as common characteristics of the commercial food sector. Besides the diversity of the food offering, it was observed that most of the restaurants have more than one

\footnotetext{
${ }^{2}$ Informal street kiosk, built in such a way that it can be easily disassembled and where several types of food and drinks are sold.

${ }^{3}$ It is important to make a cultural observation regarding these snack bars. In Brazil it is customary to have restaurant businesses open day and night, selling snacks, finger food and drinks.
}

specialty. In addition, based on the types of the restaurants and their menus, it was seen that the self-service restaurants and à la carte restaurants concentrate on the sale of meals and 'all-you-can eat' style service, while the snack bars and street food kiosks sell, mostly, snacks (e.g.: hamburgers, pizza, açaí, ice cream, hot dogs, among others) and bars sell mainly finger foods, focusing more on the sale of alcoholic beverages.

As regards the length of time the cmommercial food business surveyed had been in operation, it was found that most of them (33.3\%) had been in operation for over ten years, followed by $20 \%$ with less than one year in operation, $20 \%$ with 2 to 4 years, $13.3 \%$ with 4 to 8 years and $13.3 \%$ with 1 to 2 years in operation.

Most of the businesses surveyed (86.7\%) opened at night, from 6 p.m. to 12.30 am, followed by $20 \%$ that operated from 8 a.m. to 6 p.m. This suggests that the establishments are frequented by the workers and local residents not only for food, but also for night-time entertainment.

Gimenes (2004) points out some characteristics of consumption at night-time establishments that demonstrate the close connection between real and symbolic consumption in these spaces, emphasizing that In contemporary western societies, the forms and criteria for acquiring products and services go beyond the mere satisfaction of utilitarian necessities. Real consumption, the one related to the main characteristics of an object, and symbolic consumption, the one related to the emblematic value culturally attributed to an object, become merged, so that the act of consuming becomes an active relationship not only with the object, but also, as stated by Baudrillard (1991), with the collective and with the world, intimately linked to the cultural system of a particular society (Gimenes, 2004, p. 76) [Free translation].

According to the author, bars and other night-time establishments are generally frequented during free time, away from family and work obligations, and share some specific consumption characteristics with tourism. Also according to the same author, at these night-time establishments, the consumption is not only of food and drink but also of the atmosphere of the place, which includes fun, relaxation, and socializing with others, serving as a space of leisure and sociability.

When asked if there were any times of the year when the establishment is busier, the majority of the businesses surveyed (86.7\%) answered 'yes'. Most said the busiest months are October (75\%), November (58.3\%) and December (83.3\%), while the slower months are January (61.5\%) and February (84.6\%). In terms of the frequency with which training courses are conducted, $53.3 \%$ of the establishments said they had never done so; this may be due to the fact that they are small, informal businesses, or because they are run mostly by family members. 


\section{Profile of the workforce of restaurants on the Reta da Base Aérea de Santa Cruz}

Form 2 was used to gather information about the socioeconomic profile of workers in the bars, restaurants and other catering businesses around the Reta da Base Aérea de Santa Cruz, and the dynamics of relationships in the workplace. Seventeen available employees were found to answer the questions during the days of fieldwork, of which 13 agreed to fill out the form. Of these, $61.5 \%$ were working full-time, $23.1 \%$ as casual workers, and $15.4 \%$ part-time.

In relation to the jobs carried out, $53.8 \%$ of the employees said to had more than one job. The jobs described were: waiter/waitress (61.5\%), receptionist (61.5\%), manager $(23.1 \%)$, cashier $(23.1 \%)$, cook $(15.4 \%)$, and barman $(7.7 \%)$.

In relation to age range, the majority (61.5\%) of the responders were aged from 20 to 29 years old, and the remainder were distributed as follows: 15 to 19 years old $(15.4 \%), 30$ to 45 years old $(15.4 \%)$, and 46 to 59 years old $(7.7 \%)$.

Still on the subject of the employees' profile, the level of education was identified as follows: $53.8 \%$ said they had completed high school, followed by $23.1 \%$ who said they had only completed elementary school. The others were distributed as follows: $7.7 \%$ had not completed high school, $7.7 \%$ had not completed college, and $7.7 \%$ were postgraduates.

For $30.8 \%$ of the interviewed employees, the daily working hours were less than 8 hours; $38.5 \%$ worked 8 hours a day; $15.4 \%$ worked more than 8 hours a day; and $15.4 \%$ worked over 10 hours a day. Regarding the monthly income, $53.8 \%$ had earnings of between 0.5 and 1 minimum wages, and the rest were distributed as follows: between 1 and 1.5 minimum wages (15.4\%), between 1.5 and 2 minimum wages (15.4\%), between 2 and 2.5 minimum wages $(7.7 \%)$, and more than $3 \mathrm{mi}-$ nimum wages (7.7\%).

In the absence of an up-to-date national survey of the profile of commercial food service employees, it is appropriate to mention the survey conducted by the Pesquisa Nacional por Amostra de Domicílios [National Household Sample Survey] (PNAD) 1999, which reports that bar and restaurant employees were "on average, 35 years old, had less than seven years of study, worked 48 hours per week, and earned around $2.5 \mathrm{mi}-$ nimum wages per month" (Assunção, Rocha \& Ribas, 2010, p. 29) [Free translation]. This means that most of the workers are adults, with several years of experience in the job market, but with low levels of education and specialization, leading them to accept low wages and long working hours (Assunção et al., 2010). Also, Rocha and Amaral (2012), in their study on the profile of workers in the out-of-home food sector of the Central Coastal Region of Santa Catarina, observed that the employees had low levels of education, with $63 \%$ not having completed high school.

Comparing the results of the surveys conducted by PNAD and Rocha and Amaral (2012) with the results of our survey among restaurant workers on the Reta da Base Aérea de Santa Cruz, we see that the data on level of education differ, as the majority of the respondents in our survey (53.8\%) had graduated from high school, having completed more than seven years of studying. Even so, $23.1 \%$ had only completed elementary school completed and $7.7 \%$ had not completed high school. A few of the respondents had higher degrees, and held better positions, usually as managers, although these jobs are not always occupied by postgraduates. In general, those with higher education degrees are more likely to hold the position of manager than other restaurant positions, though this is not always the case.

The data on the workers' profile also different from the PNAD survey in relation to age, as most of the respondents of our survey (76.9\%) were aged between 15 and 29 years, with $23.1 \%$ aged from 30 to 59 years, and an average age of 27.5. The respondents of our survey were, therefore, younger and with less work experience in the market. This fact is related to the great potential the out-of-home food sector to generate job vacancies, especially first jobs, and to attract unskilled labor (Abrasel, 2020). According to Guerrier and Adib (2004), the restaurant sector employs a high number of young people, providing them with their first job experience and giving students an extra income. Added to this, $53.8 \%$ of the respondents had completed high school, and the majority (53.8\%) stated that acquiring experience is an important factor in their decision to work, as well as being independent (84.6\%) and being able to earn enough to fund their studies (46.1\%).

Meanwhile, the data on worker's individual earnings was similar in our survey to the results reported by the PNAD survey, as most of the respondents in our survey (92.3\%) earned up to 2.5 minimum wages, and $53.8 \%$ earned from 0.5 to 1 minimum wage. Despite the low salaries, $69.2 \%$ of the employees questioned did not have any other jobs, which may be related to the long working hours. Given that $69.3 \%$ of the workforce in our survey work up to 8 to 10 hours a day, this would leave little time for other paid activities.

The study by Rocha e Amaral (2012) reports that $83 \%$ of restaurant employees on the Santa Catarina Coast earned up to three minimum wages a month, while $59 \%$ earned up to 1.5 minimum wages. We also 
highlight the data from the study by Assunção et al. (2010) concerning the profile of kitchen staff of the Via Gastronômica de Coqueiros, a restaurant district in Florianópolis, Santa Catarina, which states that $17 \%$ of the workers earned up to 1.5 minimum wages per month and $83 \%$ earned up to 2.5 minimum wages. Regarding extra earnings, the study by Assunção et al. (2010) also reports that $74 \%$ of the workers did not have any extra income, given that $71 \%$ of them worked up to 8 hours daily and $18 \%$ worked 9 or more hours per day.

Considering that workers who change jobs more often are those with lower levels of education, and lower pay (Gerbelli, 2017), it is possible to relate these factors to the high level of staff turnover found in the surveyed establishments, since most of the employees (61.5\%) said they had been in their current jobs for less than a year. This high employee turnover might indicate a need for workers to fill vacancies at new businesses that have been emerging each year. However, $46.2 \%$ of the employees said they had worked in the same job for less than a year, but only $20 \%$ of the establishments had been open for less than a year.

Rocha and Amaral (2012)'s study also demonstrates a Source: Elaborated by the authors $(2021)^{8}$.

high level of turnover among restaurant staff in the Santa Catarina Central Coast Region: $76 \%$ of the employees had been in the same job for less than three years and $45 \%$ for less than one year. According to Assunção et al. (2010) 63\% of kitchen workers from Via Gastronômica de Coqueiros in Florianópolis had been in the job for less than a year. However, in the research of Assunção et al. (2010), this does not correspond to an increased need for new workers, since only $23 \%$ of them had worked in the food and beverage sector for less than a year.

Through the results of our study, we observed that besides the workers although the majority of the workers were from the South East region (69.2\%), 30.8\% were from the Center-West region, indicating a migration of the workforce from different states of Brazil. The migrating workforce is generally comprised of people looking for better jobs, a better quality of life, and they often end up working in the commercial food sector, as these jobs often require no academic or professional qualifications (Assunção et al., 2010). This factor may also indicate a relationship with the Santa Cruz Air Base, as it is a unit that is subordinated to the country's capital, which is in the Center-West region.

Meanwhile, most of the surveyed employees (84.6\%) lived in the Santa Cruz neighborhood. The same occurred in the results of Assunção et al. (2010), with 60\% of the workers living near their workplace, which in some cases, was described as a requirement of the employer. Regarding sex, $53.8 \%$ of the respondents of our study were female and $46.2 \%$ were male, indicating a predominantly female population of workers. Similar results were found by Assunção et al. (2010), with 54\% females and $46 \%$ males. This percentage may be related to the results of the 2018 Continual National Household Sample Survey concerning women in the job market, which states that women are more prevalent among the services, retail and market workers, representing 59\% (IBGE, 2019b).

Nevertheless, studies indicate that women still earn $20.5 \%$ less than men. The data that indicate this "relate to the fourth trimester 2018, considering only people aged 25 to 49 years, and show that the disparity in the average monthly earnings between men $(R \$ 2,579)$ and women $(R \$ 2,050)$ is still $R \$ 529 "$ (Paradella, 2019, p. 1) [free translation]. The disparity is even greater among the service, retail and market workers, where the monthly earnings difference is $\mathrm{R} \$ 663$ (IBGE, 2019b). This is in agreement with our study of commercial food business workers at the Reta da Base Aérea de Santa Cruz, in which it was observed that men earned around half a minimum wage more than women, even if they have the same job position.

As regards race, $53.8 \%$ of the workers the employees surveyed in this research territorial sample declared themselves to be Pardo ${ }^{4}$, followed by $23.1 \%$ Black, $15.4 \%$ White and $7.7 \%$ Indigenous. Thus, $84.6 \%$ of the workforce were non-White, supporting the fact nonWhite people live mainly in the poorer areas of Rio de Janeiro, i.e. to the north and west of the city (Clarke, 2015).

Despite some problems, such as the low pay and long working hours, most of the respondents said they were content in their current job, as shown by their agreement with the following statements: "I work here willingly" (61.54\%), "I consider my job to be interesting and rewarding" (69.23\%) and "I feel appreciated in my job" (69.23\%). However, the current scenario has high rates of unemployment, which may affect how much people are willing to hang onto the jobs they have got. Another fact was that the majority (76.9\%) of the respondents said they would not change their work team, justifying this with positive statements such as "because they are good at what they do" and "they are excellent employees". Also, all the respondents said they would not change their management, some even supporting their answers with comments like: "my boss is a good boss", "I am satisfied", "they are good bosses". However, it should be noted that some employees filled out the forms with coworkers next to them, and might not have wanted to make any negative comments in case their answers were read by others.

Concerning the relationship between employees and customers, $53.8 \%$ said they had an excellent relationship with the customers, while $46.2 \%$ said this relations-

${ }^{4}$ Pardo' is the term used by the Brazilian Institute of Geography and Statistics (IBGE) censuses to denote persons with brown skin who do not identify as Black. 
hip was very good. Also, most of the respondents (84.62\%) agreed with the statement: "some of my customers are also my friends".

It should be noted that these aspects may be related to small business, and the same may not be true of franchises or more formal businesses. Franchised restaurants, usually characterized by the fast-food concept, operate in environments where stress levels are high, and employees need to work quickly, following standard operational procedures to serve the customer, and there is less tolerance for errors (Arend \& Reis, 2009). According to Guerrier e Adib (2004), in less formal hospitality environments, employees become friends, while the opposite is true of more traditional and formal ones, where the ideal worker is someone who is able to keep his emotions in check and act on autopilot.

Considering the facts presented above, it is important to mention that "the hospitality sector employee quality is influenced by the way they are treated by their employer, as well as how they are considered by the customer" (Guerrier \& Adib, 2004, p. 380) [Free translation]. Also, according to Forte (1982 as cited in Guerrier \& Adib, 2004), in the services sector, the most important factor of the product is the person. Therefore, the human resource aspect is the one that determines quality of the service to be offered to the clients, and consequently, its success in the market.

\section{CONCLUSION}

This paper aims to characterize socioeconomic profile of the workforce of bars, restaurants, and similar establishments in the territorial sample of the Santa Cruz neighborhood: the Reta da Base Aérea, focusing on a topic that has been little studied within the fields of study of hospitality, tourism and leisure: the characterization of the workers in these areas.

Based on our results, it is concluded that is it possible to characterize the workforce of restaurants around the Reta da Base Aérea de Santa Cruz, to determine the work relationships between the local restaurant managers and their employees, and to identify which restaurants offer out-of-home food during leisure periods for local residents of a territorial sample on the outskirts of the city that is not yet popular with tourists. The importance of these results is emphasized, in view of the lack of data on the workforce of this sector, especially outside the field of tourism.

Through this work process, academics can disseminate and assist in the future creation of projects for tourism development and leisure planning in the region. A tourism qualification policy can also be considered aimed at social inclusion and economic development, through the generation of jobs and income. Some questions to future analyses are included, such as whether the presence of a tourist route or gastronomic complex results in higher salaries for workers, and whether the inexistence of a coordinated plan among restaurants makes the existence of a leisure destination, or a tourist destination in the Santa Cruz neighborhood, inviable.

\section{States PARKS}

Table 2 (two) lists the state parks in the state of Amazonas. In this case, the scope for sharing between other municipalities or states is smaller. In this way, it is noted that in Apuí is where the Sucunduri state park is located, and where the oldest geological domains of the Apuí mosaic are. This factor generates a different configuration in the local relief, marked by the presence of plateaus among the Amazon depression, and for this reason also known as Chapadas da Amazônia ${ }^{3}$.

Part of these parks is also characterized by overlapping with indigenous lands, such as Serra do Araçá and Matupiri. In the case of Parest Guariba, there is a concentration of a great variety of mosaic habitats, with terra firme forests, flooded forests, rupestrian fields, meadows and campinaranas, and the enormous scenic beauty provided by the falls and rapids. The rapids of Monte Cristo and the falls of the Sucunduri River are among the best-known landscapes for their attractive charm $^{4}$.

Parest Sumaúma is located in one of the most populous areas of the urban perimeter of Manaus, it is one of the few protected urban forest fragments. Two sources within the park form a tributary of the Igarapé do Mindú, which crosses the city. According to Oliveira (2012), Sumaúma can serve as a showcase for the Conservation Units of the State of Amazonas. The fact that it is located in the urban area, has a strong appeal to public visitation, is an ideal space for environmental education in schools in Manaus, especially those located in the northern part of the city, should be seen as an opportunity.

In Parest Rio Negro North Section, about 30 families live in the vicinity of the Park, with the most inhabited communities being those of Castanho and Airão Velho, where the ruins of the first portuguese city on the $\mathrm{Ne}$ gro River, from the 16th century. The main access is by boat, through the Negro River. A good part of the families residing in the Park lives exclusively from

\section{REFERENCES}

\footnotetext{
Abrasel. (2020). Perfil da Abrasel. Retrieved May 14 2020, from https://abrasel.com.br/abrasel/perfilda-abrasel/
} 
Agência Força Aérea. (2016). Dos dirigíveis aos caças: Hangar inaugurado em 1936, que servia de abrigo aos Zeppelins, é um marco para a aviação no Brasil. Retrieved April 29, 2019, from http:// www.fab.mil.br/noticias/mostra/28741/ AEROVIS\%C3\%830\%20-\%20Dos\%20dirig\%C3\% ADveis\%20aos\%20ca\%C3\%A7as

Arend, S. M. F., \& Reis, A. M. D. (2009, December). Juventude e restaurantes fast food: A dura face do trabalho flexível. Revista Katálysis, 12(2), 142151.

Assunção, A. T. C., Rocha, F. G., \& Ribas, L. C. C. (2010, December). Perfil dos trabalhadores de cozinha da Via Gastronômica de Coqueiros e notas sobre a qualificação profissional no setor de alimentos e bebidas em Florianópolis/SC. Revista Brasileira de Pesquisa em Turismo, 4(3), 24-40.

Brandão, H. A., \& Pereira, F. A. (2010, September 25th to 29th). Fontes de vantagem competitiva sustentável do pólo de gastronomia de Pernambuco: Uma visão baseada em recursos. ANPAD - Associação Nacional de Pós Graduação e Pesquisa em Administração. XXXIV Encontro da EnANPAD 2010. Rio de Janeiro, RJ, Brasil, 34

Camargo, L. O. L. (2003). Os domínios da hospitalidade. In A. F. M. Dencker, \& M. S. Bueno (Eds.). Hospitalidade: Cenários e oportunidades (pp. 7-28). São Paulo: Pioneira Thomson Learning.

Clarke, F. (2015). Mapas mostram a segregação racial no Rio de Janeiro. Retrieved May 14,2020, from https://rioonwatch.org.br/?p=17005.

Costa, B. (2013). Oscar Niemeyer assina obra na Base Aérea de Santa Cruz, em homenagem aos excombatentes da Segunda Guerra Mundial. Retrieved June 22, 2020, from extra.globo.com/noticias/rio/zona-oeste/oscarniemeyer-assina-obra-na-baseaerea-de-santacruz-em-homenagem-aos-ex-combatetes-dasegunda-guerra-mundial7195099.htm

Diário do comércio. (2019). Setor de alimentação fora do lar movimentou R\$ 205 bilhões em 2018 Retrieved May 14, 2020, from https:// diariodocomercio.com.br/negocios/setordealimentacao-fora-do-lar-movimentou-r-205bilhoes-em-2018/

Fratucci, A. C. (2002). Book review: "Gestão de pólos turísticos" de Mário Petrocchi. Caderno Virtual de Turismo, 2(3), 1-3. Retrieved July 29, 2020, from http://www.ivt.coppe.ufrj.br/caderno/ index.php/caderno/article/download/20/18

Gerbelli, L. G. (2017). Rotatividade no mercado de trabaIho se mantém elevada. Retrieved May 14, 2020, from https://exame.abril.com.br/economia/ rotatividade-no-mercado-de-trabalhosemantem-elevada/

Gimenes, M. H. (2004, May 30). Bares e casas noturnas: Um estudo exploratório sobre consumo e sociabilidade. Revista Turismo em Análise, 15(1), 7388.

Gomes, C. (2008). Antecedentes do capitalismo. Portugal: Almada.

Grupo GS\& Gouvêa de Souza. (2019). Foodservice brasileiro segue tendência de crescimento. Retrieved
June $\quad 12, \quad 2020$ from https:// grupogouveadesouza.com.br/2019/07/10/ foodservice-brasileirosegue-tendencia-de- crescimento/

Guerrier, Y. \& Adib A. (2004). O trabalho na indústria da hospitalidade. In C. Lashley, \& A. Morrison (Eds.), Em busca da hospitalidade: perspectivas para um mundo globalizado (pp. 357-386). São Paulo: Manole.

Instituto Brasileiro de Geografia e Estatística. (2019a) Pesquisa de orcamentos familiares 2017-2018: Primeiros resultados. Rio de Janeiro: IBGE.

Instituto Brasileiro de Geografia e Estatística. (2019b). Pesquisa Nacional por Amostras de Domicílios Contínua: Mulheres no mercado de trabalho. Rio de Janeiro: IBGE.

Lashley, C. (2004). Para um entendimento teórico. In C. Lashley, \& A. Morrison (Eds.), Em busca da hospitalidade: perspectivas para um mundo globalizado (pp. 1-24). São Paulo: Manole.

Machado, S. (2013a). Em Santa Cruz, riqueza histórica e empreendedorismo. Retrieved April 10, 2019, from http://www.multirio.rj.gov.br/index.php/ leia/reportagens-artigos/reportagens/488santacruz-riqueza-historica-e-vocacao-para-oempreendedorismo

Machado, S. (2013b). Investimento bilionário no Distrito Industrial. Retrieved June 23, 2020, from http:// www.multirio.rj.gov.br/index.php/leia/ reportagens-artigos/reportagens/490- investimento-bilionario-no-distrito-industrial

Machado, S. (2013c). Prestígio e vanguarda desde o império. Retrieved June 23, 2020, from http:// www.multirio.rj.gov.br/index.php/leia/ reportagens-artigos/reportagens/489- prestigioe-vanguarda-desde-o-imperio

Mansur A L (2008). O velho oeste carioca: A história da Zona Oeste do Rj de Deodoro a Sepetiba do século XVI ao XXI. Rio de Janeiro: IbisLibris.

Oliveira, M. A. S. A. (2017). Zona Oeste da cidade do Rio de Janeiro: Entre o rural e o urbano. Revista lluminuras, 18, p. 325-349.

Paradella, R. (2019). Diferença cai em sete anos, mas mulheres ainda ganham 20,5\% menos que homens. Retrieved June 18, 2020, from https:// agenciadenoticias.ibge.gov.br/agencianoticias/2012- agencia-de-noticias/ noticias/23924-diferenca-cai-em-sete-anos-masmulheres-aindaganham-20-5-menos-quehomens

Rocha, F. G., \& Amaral, F. M. (2012, April). Qualificação para as atividades do turismo: perfil profissional de trabalhadores, proprietários e gestores de empresas de alimentação fora do lar na região litorânea central do estado de Santa Catarina (Brasil). Turismo \& Sociedade 5(1), p. 124-143.

Salay, E. (2005). Consumo alimentar fora do domicilio: Implicações para pesquisas em segurança alimentar e nutricional. Com Ciência: Revista eletrônica de jornalismo científico. Retrieved May 14 2020, from http://www.comciencia.br/dossies-172/reportagens/2005/09/14.shtml 
Soares, E. A. (2016). O bairro turístico gastronômico da Varjota em Fortaleza: Desvendando a cozinha tradicional cearense. Dissertação de mestrado, Universidade Estadual do Ceará. Fortaleza, CE, Brasil.

Souza, S. N. (2003). Fazenda Real de Santa Cruz: Patrimônio histórico. Retrieved April 29, 2019, from https://www.ucs.br/site/midia/arquivos/96-

fazenda-real-de-santa-cruz.pdf 